\title{
Meloidogyne hapla, the Northern Root-Knot Nematode, in Florida Strawberries and Associated Double- Cropped Vegetables ${ }^{1}$
}

\author{
J. Desaeger ${ }^{2}$
}

Root-knot nematodes (Meloidogyne spp.) do not occur commonly on strawberry (Fragaria X ananassa) in Florida. Incidences of their infestations in strawberry-growing areas of the state have been reported only occasionally and attributed to the northern root-knot nematode (Meloidogyne hapla) (NRKN) (Howard et al. 1985; Noling and Whidden 2010). These preliminary identifications were confirmed subsequently by molecular analyses conducted by Nyoike et al. (2012). An increase in detection of damage induced by NRKN on strawberry has been observed frequently in recent years, and often growers mistakenly associate what is actually NRKN damage with sting (Belonolaimus longicaudatus) nematode infestations. The adverse effect of NRKN on strawberry production remains largely unknown to strawberry growers in Florida because of lack of information about biology and behavior of this nematode on strawberry in the state.

This publication is intended to educate and provide information on this nematode to researchers, extension agents, growers, industry representatives, and other stakeholders in the strawberry and vegetable community.

\section{Importance, History, and Distribution}

Plant-parasitic nematodes are small roundworms that cause tremendous economic damage in agriculture and horticulture. Their microscopic size and transparent cuticle make them difficult to detect and to identify. Most nematodes occur in soil or in subterranean plant parts where they feed on living plant tissues, often resulting in below- and aboveground symptoms such as root galls, lesions, stunting, wilting, or chlorosis. Nematodes are estimated to cause more than $10 \%$ of all worldwide plant losses, which translates into over $\$ 100$ billion dollars annually. By far, root-knot nematodes (Meloidogyne spp.) (RKN) are the most common and destructive plant-parasitic nematodes globally. Although they tend to cause most damage in the tropics and sub-tropics, they are found in all agricultural regions worldwide.

The RKN species that are most common in Florida are M. incognita, $M$. javanica, and M. arenaria. Because these species thrive in warm climates and in regions between $30^{\circ} \mathrm{N}$ and $35^{\circ} \mathrm{S}$ latitude, they are called thermophilic RKNs (Karssen et al. 2013). The NRKN is one of the most common root-knot nematodes in temperate climates. Although

1. This document is ENY-070, one of a series of the Department of Entomology and Nematology, UF/IFAS Extension. Original publication date October 2018. Visit the EDIS website at https://edis.ifas.ufl.edu for the currently supported version of this publication.

2. J. Desaeger, assistant professor, Department of Entomology and Nematology, UF/IFAS Gulf Coast Research and Education Center, Wimauma, FL 33598

The use of trade names in this publication is solely for the purpose of providing specific information. UF/IFAS does not guarantee or warranty the products named, and references to them in this publication do not signify our approval to the exclusion of other products of suitable composition.

The Institute of Food and Agricultural Sciences (IFAS) is an Equal Opportunity Institution authorized to provide research, educational information and other services only to individuals and institutions that function with non-discrimination with respect to race, creed, color, religion, age, disability, sex, sexual orientation, marital status, national origin, political opinions or affiliations. For more information on obtaining other UF/IFAS Extension publications, contact your county's UF/IFAS Extension office. 
it thrives in locations north of $39^{\circ} \mathrm{N}$, it also can be found in high elevations of tropical regions. This species of RKNs and others that thrive in cold climates are called cryophilic.

The NRKN was first described from a potato field in Long Island, New York (Chitwood 1949). This parthenogenetic (asexually reproducing) species parasitizes nearly all temperate vegetables of economic importance and can considerably reduce yield, even causing total crop loss.

A serious pest of strawberry in all temperate growing strawberry regions (the northeastern United States, Canada, and Europe), NRKN is only a minor pest in California. In Florida, where the main nematode damaging strawberry is sting nematode (Belonolaimus longicaudatus), NRKN has not been considered a major problem. Diagnostic studies have been conducted recently in cooperation with Dr. J. Brito of the Florida Department of Agriculture and Consumer Services Division of Plant Industry (FDACSDPI) to characterize RKN populations from several farms in areas of Plant City, Florida. The results of these analyses have confirmed a wider distribution of NRKN in the state than previously thought (J. Desaeger, unpublished). These findings agree with results of the study conducted by Nyoike et al. (2012), who implied that NRKN infestations of Florida strawberry originated from Canada due to the use of nematode-infested strawberry transplants from that country.

\section{Biology and Ecology}

Meloidogyne species, including M. hapla, are non-segmented roundworms, with six life stages: the egg, four larval or juvenile stages, and the adult. Their mouth parts include a needle-like, hollow spear or stylet. The nematode feeds by inserting its stylet into a plant cell, injecting digestive enzymes into the cell, and drawing digested cell components back through the stylet into its digestive system.

All root-knot nematodes are obligate sedentary endoparasites of plant roots and tubers, meaning that they enter the root and establish a feeding site from which they do not move. They induce small or large root swellings called root-knots or galls. Their infective second-stage juveniles (J2) hatch from the eggs in the soil and penetrate the tip of a suitable root where they develop into sedentary and swollen juveniles and adult females (Figure 1). Males are wormlike, not parasitic and exit the root when they reach adulthood in search of suitable females to mate with. All root-knot nematodes induce formation of specialized trophic sites (feeding sites) called giant cells that provide essential nutrients for their development and egg production. The formation of giant cells is associated with hyperplasia (enlargement) of the tissues surrounding the feeding site. Adult females produce many eggs (up to and often more than 1000) encased in a protective gelatinous matrix.

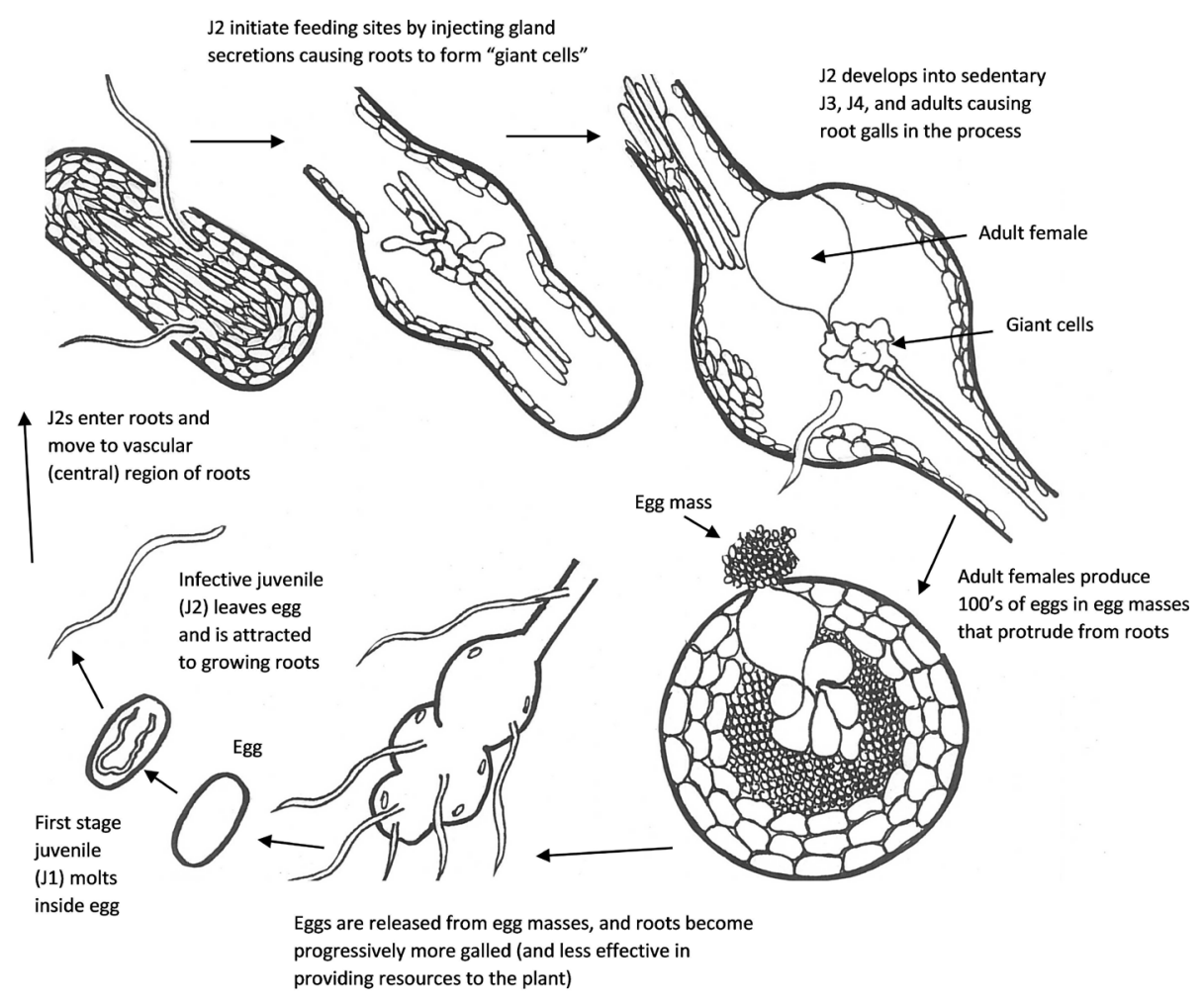

Figure 1. Life cycle of the root-knot nematode Meloidogyne spp.

Credits: courtesy H. Regier, adapted from G. Abawi and V. Brewster (2003) 
Unlike most other root knot nematode species of warm climatic areas, $M$. hapla eggs and juveniles can survive field temperatures below $0^{\circ} \mathrm{C}$. M. hapla seems to be less tolerant of high temperatures than the thermophilic Meloidogyne spp. The optimum temperature for invasion and development of $M$. hapla is in the range $20-25^{\circ} \mathrm{C}$. A mean temperature of $27^{\circ} \mathrm{C}$ may prevent its development, even if some populations of this nematode can develop and reproduce on alfalfa at $30^{\circ} \mathrm{C}$ under controlled environmental conditions (Griffin et al. 1986). The nematode's mild temperature requirement explains why it typically shows up in Florida strawberry fields in the second half of the season (January-March) when soil temperatures are cool.

There is no conclusive evidence about the inability of NRKN to survive the hot summer conditions of Florida when soil temperatures exceed $30^{\circ} \mathrm{C}$. We have indications that, in at least one strawberry field, damage and presence of NRKN persisted for two consecutive years (2017-2018). The nematode infestation was ascertained at first at the end of the strawberry crop (March 2017) and subsequently detected again in the same area of the field the year after at the end of the successive strawberry crop (March 2018). However, to prove conclusively that the nematode can survive and become established in Florida, more definitive sampling needs to be done from other fields where NRKN was found.

\section{Hosts/Species Affected}

Like all root-knot nematodes, $M$. hapla has a wide host range. Good hosts are vegetables, forage and seed legumes, and tubers; grasses and cereals are usually comparatively poor hosts. In Florida, M. hapla seems to be the only RKN species that causes damage to strawberry. None of the more common thermophilic RKN species in Florida seem to cause any damage to this crop. In North Carolina, for instance, the southern RKN species $M$. incognita does not cause damage on strawberry (Averre et al. 2011).

Our field observations indicate that, in addition to strawberry, NRKN can also cause considerable damage to many vegetables that are double-cropped with strawberry in Florida. These vegetables include cantaloupe and watermelon that are grown as a double-crop in strawberry beds (Figure 2). When M. hapla is present in the beds, these double-crops can be severely infected by the nematode, with significant plant mortality and sometimes complete crop loss (Figure 2, right).

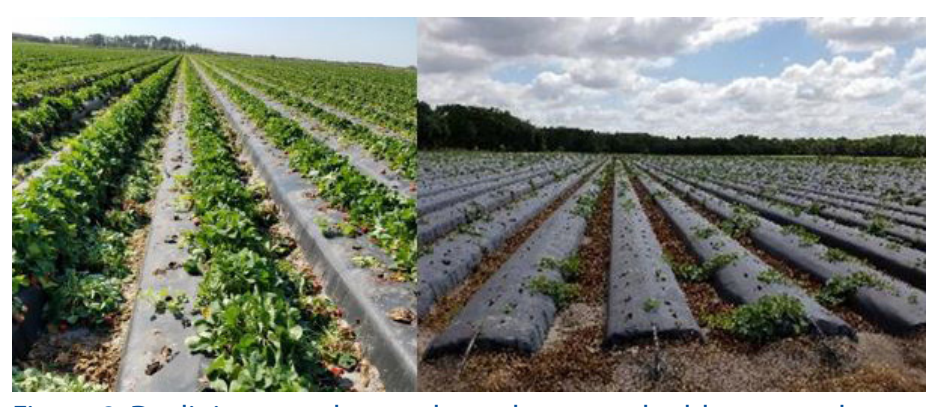

Figure 2. Declining cantaloupe plants that were double-cropped in strawberry beds infested by the northern root-knot nematode (Meloidogyne hapla); left: beds with a row of strawberry flanked on the left by a row of stunted and small cantaloupe plantlets. Cantaloupe were replacing a preexisting row of strawberry infected by the nematode; right: stunted and patchy stands of nematodeinfected cantaloupe planted as a double-crop in nematode-infested strawberry beds in Plant City, FL, March 2017.

Credits: J. Desaeger

\section{Damage Symptoms}

Aboveground symptoms of NRKN include stunted plants, discolored leaves, and overall reduced yield. In general, severe attack by $M$. hapla will result in badly impaired root function and concomitant stunting of the aboveground parts, reducing yield. Symptomatic plants characteristically occur in scattered clumps because of the patchy distribution of the nematodes. Like all root-knot nematodes, NRKN induces galls or knots in the root system.Unlike such thermophilic RKN species as M. arenaria, M.incognita, and $M$. javanica, which often cause large, coalesced galls that can cover the entire root system (Figure 3), the galls formed by NRKN are usually smaller and more discrete, as is the case on strawberry (Figure 4).

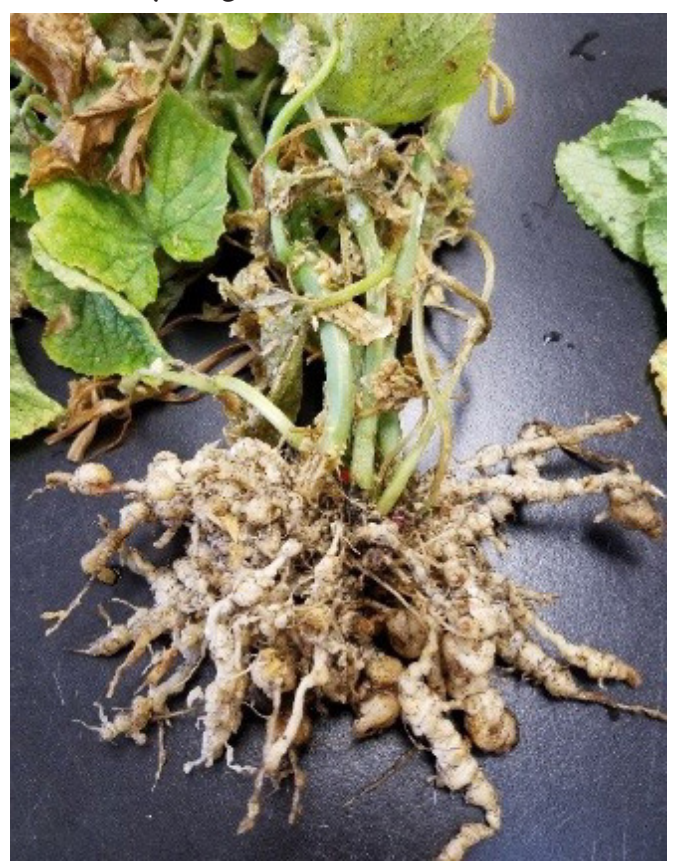

Figure 3. Root galls on cucumber caused by the Javanese root-knot nematode Meloidogyne javanica at GCREC in 2017.

Credits: J. Desaeger 


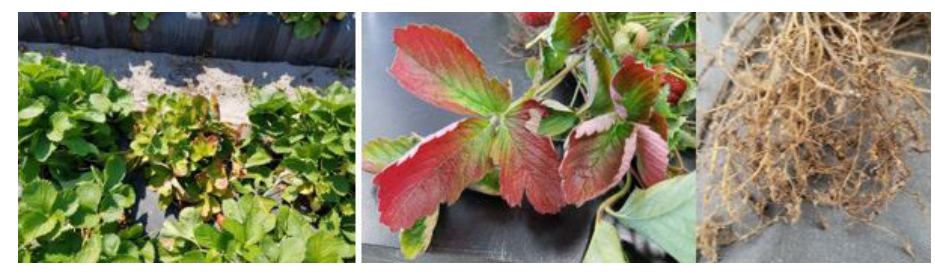

Figure 4. Strawberry damage (shoot and root) due to the parasitism of the northern root-knot nematode (Meloidogyne hapla). Left and middle: a plant with reddish and chlorotic leaves among asymptomatic plants; right: a nematode-infected root system showing small, round, and discrete galls from a field in Plant City, FL, in March 2017. Credits: J. Desaeger

Strawberry plants infected with NRKN may be stunted, with a reddish or yellowish discoloration of the leaves.

Aboveground symptoms may look like those of sting nematode damage, and the two can be easily confused. However, root-knot nematode damage on strawberry in Florida typically shows up towards the end of the season (February-March), whereas sting nematode damage normally occurs earlier in the season. Often the presence of NRKN in strawberry is not very evident. Infected plants may appear normal because they become well developed before the winter time, when NRKN becomes more active and infective. If the strawberry root system is well established by the time soil temperatures decrease and become more optimal for the nematode, the plants will be much hardier and more tolerant and may withstand the nematode's parasitism.

On young cantaloupe plants, root galls can be much more pronounced than on strawberry, and can overwhelm the entire root system, turning it into one large clump of root galls and causing seedling mortality and complete crop loss (Figure 5). Double-cropped vegetables that are planted after strawberry are exposed to much higher levels and more active nematodes at the time of planting and in the early stage of their growth than strawberry at the beginning of the season. Direct-seeded vegetables are more vulnerable to NRKN damage because their young roots are parasitized by the nematode as soon as they develop from the seed (Figure 5).

\section{Detection and Identification}

Nematodes are often unnoticed because they are difficult to detect and identify. Aboveground nematode damage symptoms are often confused with damage caused by bacteria, fungi, viruses, nutrient deficiencies, chemical injuries, or other problems (such as suspected plugged drip tapes). Plant-parasitic nematodes should be always considered as a potential detrimental factor when the cause of a plant problem or an instance of poor crop growth cannot be definitively diagnosed. This is especially true in Florida, where nematodes are extremely common and capable of causing significant crop losses.
Root-knot nematode infections can be easily diagnosed by the presence of galls in the nematode-parasitized roots. Gall size and severity can vary greatly depending on plant host and RKN species, as stated and shown previously (Figures 4 and 5). Nematode identification requires the extraction of the motile stages (J2 and males) from the soil and roots and the swollen females from the root tissues and examining them with the aid of stereo or compound microscopes.

NRKN is one of the most morphologically variable RKNs, with high variability in shape and structural relationships within the species. Two races with different chromosome numbers and reproductive habits have been reported for this species (Karssen et al. 2013). A morphological identification of NRKN must be confirmed by molecular and biochemical analyses. Polymerase chain reaction (PCR) assays and iso-enzymatic analyses to study the patterns of migration of enzymes are conducted at UF, FDACS-DPI, and the GCREC to assist in the rapid differentiation of RKN species. These analyses are conducted by specialized nematologists.

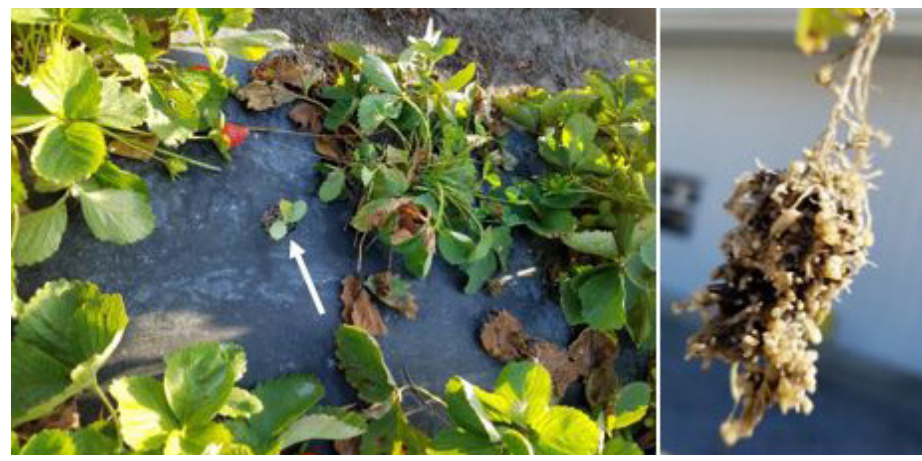

Figure 5. Damage of the northern root-knot nematode (Meloidogyne hapla) on cantaloupe. Left: a stunted cantaloupe seedling (indicated by arrow) growing among declining nematode infected strawberry plants; right: a stunted young cantaloupe plant removed from a nematode-infested strawberry bed showing the root system galled and deformed by the nematode in Plant City, FL, in March 2017. Credits: J. Desaeger

\section{Dissemination}

NRKN was most likely introduced to Florida with infected strawberry transplants from northern nurseries (Figure 6). The study conducted by Nyoike et al. (2012) provides evidence of presence of NRKN in strawberry replants from Canada, where this nematode is quite common in strawberry fields. In 1993, NRKN was found in 7\% of strawberry fields in Quebec (Belair and Khanizadeh 1994), and in 2014 it was found in $42 \%$ of strawberry fields in Ontario (Patterson 2015). Likely the disappearance of methyl bromide and use of less-effective nursery pest-management practices has increased the presence of soil pests such as NRKN and root-lesion nematodes in northern strawberry nurseries. Because these nurseries provide Florida growers with transplants, nematodes like NRKN have become more common in Florida strawberry farms. 


\section{Management}

Understanding the spread, survival, and damage potential of NRKN is the first step in dealing with them. It is also critical to identify means and methods to limit introduction of these nematodes with transplant material. Production of nematode-free nursery plants is the first and most important tactic to manage nematodes. Especially for strawberry, this starts at the source of the transplants, by selecting nursery fields that are free of nematodes and by treating transplants before they are shipped or planted. Hot water treatment can be effective, but is not an option for FL growers because it delays blooming. Also, soil fumigation will not provide protection against nematodes when they are introduced with transplants. Nematode-infected transplants growing in fumigated soil usually suffer more damage than in non-fumigated soil because the NRKN thrives in fumigated soil where there are no competing nematodes, biological antagonists, or natural enemies.

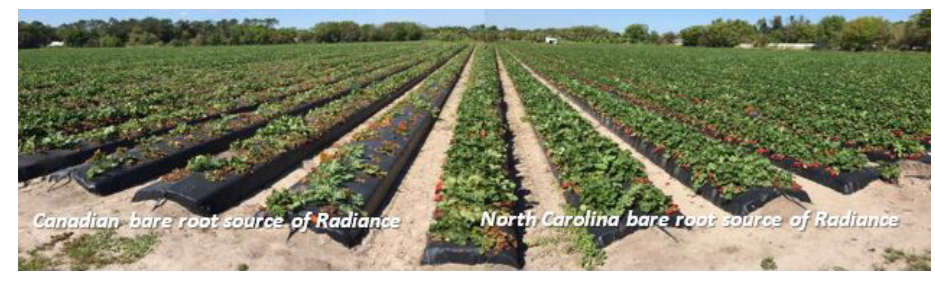

Figure 6. Strawberry field in Plant City, FL, in March 2016 with transplants of 'Florida Radiance' strawberry from different nursery sources. Left: late-season collapse of Canadian transplants infected with northern root-knot nematode; right: same field but with nematode-free transplants from NC.

Credits: J. Noling

There are no good management practices for heavy NRKN infestations; the key is to implement management strategies preventively or upon early detection of their presence. However, for those fields where NRKN are already established, it is important to manage the existing populations. The wide host range, including many weeds, makes it extremely difficult to manage a root-knot nematode problem. Non-chemical methods include frequent cultivation of the land (exposing nematodes to the sun) and crop rotation with non-host cereal crops or sunn hemp, all of which may help to suppress NRKN. Chemical management may include soil fumigants like 1,3-D, metam, and DMDS, and non-fumigant drip-applied nematicides such as fluensulfone $\left(\right.$ Nimitz $\left.^{\circledR}\right)$, fluopyram (Velum ${ }^{\odot}$ ), oxamyl $\left(\right.$ Vydate $^{\odot}$ ) (only on vegetables, not on strawberries), and biological products such as Burkholderia (Majestene ${ }^{\oplus}$ ). For more info on nematicides please refer to other EDIS publications ENY032, ENY033, ENY041, ENY064 and ENY065.

\section{References}

Averre, C.W., W. O. Cline, R. K. Jones, and R. D. Milholland. 2011. "Diagnosis of strawberry diseases." North Carolina Cooperative Extension Service, North Carolina State University, Raleigh, NC. https://content.ces.ncsu.edu/ diagnosis-of-strawberry-diseases Accessed June 2018.

Bélair, G, and S. Khanizadeh. 1994. "Distribution of plantparasitic nematodes in strawberry and raspberry fields in Quebec." Phytoprotection, vol. 75, n 2, p. 101-107.

Griffin, G. D., R. N. Inserra, N. Vovlas, and D. V. Sisson. 1986. "Differential reaction of alfalfa cultivars to Meloidogyne hapla and M. chitwoodi populations." Journal of Nematology 18:347-352.

Howard, C. M., A. J. Overman, J. F. Price, and E. E. Albregts. 1985. Diseases, Nematodes, Mites, and Insects Affecting Strawberries in Florida. University of Florida Institute of Food and Agricultural Sciences, Agricultural Experimental Station. Bulletin 857: 52.

Karssen, G., W. Wesemael, and M. Moens. 2013. Root-knot nematodes. In R. N. Perry \& M. Moens (eds.) Plant Nematology (pp.73-108). Wallingford, UK: CAB International.

Noling, J. W., and A. Whidden. 2010. "International issues and growing concerns for new nematode problems in the Florida strawberry industry." Berry/VegetableTimes, June 2010, UF/IFAS Extension, University of Florida, Gainesville, FL.

Noling, J. 2015. Fumigants registered for vegetable crop use in Florida. ENY-064. Gainesville: University of Florida Institute of Food and Agricultural Sciences. http://edis.ifas. ufl.edu/in980. Accessed June 2018.

Nyoike, T. W., T. Mekete, R. McSorley, E. Weibelzahl-Karigi, and O. E. Liburd. 2012. "Identification of the root-knot nematode, Meloidogyne hapla, on strawberry in Florida using morphological and molecular methods." Nematropica 42:253-259.

Patterson, J. 2015. "Population Dynamics and Management of Plant-Parasitic Nematodes in Commercial Strawberry (Fragaria $x$ ananassa) Fields of Southern and Eastern Ontario." MSc Thesis, The University of Guelph. Guelph, Ontario, Canada https://atrium.lib.uoguelph.ca/xmlui/bitstream/handle/10214/8827/Patterson_John_201505_Msc. pdf;sequence $=1$. Accessed June 2018. 